\title{
Genetic variation in the planktonic chaetognaths Parasagitta elegans and Eukrohnia hamata
}

\author{
Erik V. Thuesen ${ }^{*}$, Ken-ichi Numachi, Takahisa Nemoto** \\ Ocean Research Institute, University of Tokyo, 1-15-1 Minamidai, Nakano-ku, Tokyo 164, Japan
}

\begin{abstract}
Two species of planktonic chaetognaths, Parasagitta elegans (Verrill) and Eukrohnia hamata (Möbius), from waters off Japan were analyzed electrophoretically and found to display very low levels of genetic variability. Nineteen enzyme loci were examined for 7 population samples of $P$. elegans, and the proportion of polymorphic loci $\left(P_{0.95}\right)$ and average frequency of heterozygotes per locus $(H)$ were calculated as 0.11 and 0.026 , respectively. Fifteen enzyme loci were examined for 2 populations of $E$. hamata, and $P_{0.95}$ and $H$ were calculated as 0.10 and 0.038 , respectively. On the basis of allele frequencies at 2 enzyme loci it is possible to suggest that $P$. elegans population samples collected in the Sea of Japan were reproductively isolated from those in the Oyashio. Moreover it would appear that 4 population samples of $P$. elegans in the Sea of Japan are representative of a panmictic population. Differences in allele frequencies between population samples of the Oyashio suggest that these popuiations are genetically structured. It appears that genetic structuring exists in the 2 population samples investigated for E. hamata also. P. elegans and E. hamata expressed no common alleles over all the loci assayed indicating that the 2 species are phylogenetically very distant within the phylum Chaetognatha.
\end{abstract}

\section{INTRODUCTION}

The small marine phylum Chaetognatha is composed primarily of holoplanktonic predators which feed mainly on copepods. Although they are commonly the largest constituent of carnivorous zooplankton biomass in the earth's oceans, little is known of chaetognath population structure. In recent years advances have been made in understanding the population structure of other marine zooplankters through analyses of electrophoretically detectable differences in enzymes. Since these differences usually result from variations in the amino acid sequence of the enzyme which are controlled by changes in the DNA, they can be considered single locus genetic markers and used to determine genetic differences between conspecific populations (Nei 1972).

\footnotetext{
- Present address: Oceanic Biology Group, Marine Science Institute, University of California, Santa Barbara, California 93106, USA

- Deceased
}

Ayala et al. (1975) were the first to perform biochemical genetic studies of zooplankton populations when they analyzed genetic variability in the antarctic krill Euphausia superba. As the study of krill populations has attracted the attention of biologists for decades, many other species of krill were also soon analyzed electrophoretically, including E. mucronata and E. distinguenda (Valentine \& Ayala 1976), E. crystallorophias (Fevolden \& Ayala 1981), Meganyctiphanes norvegica and Thysanoessa raschi (Fevolden 1982), E. pacifica (Fevolden 1986) and E. krohnii and Nematoscelis megalops (Bucklin \& Weibe 1986). In addition to krill, several other planktonic crustacea have been investigated, the copepods Labidocera aestiva (Bucklin \& Marcus 1985) and Metridia pacifica (Bucklin et al. 1989, Bucklin 1991), as well as 4 species of hyperiid amphipods, Themisto compressa, T. abyssorum, T. libellula and T. gaudichaudii (Schneppenheim \& Weigmann-Haass 1986).

Most of these authors and others (e.g. Schneppenheim \& MacDonald 1984, Kühl \& Schneppenheim 1986) have generaily found these planktonic popula- 
tions to have high levels of genetic homogeneity within the sampling areas. Fevolden \& Schneppenheim (1988, 1989) carried out further electrophoretic investigations on Euphausia superba and were not able to discriminate among populations in the Pacific, Atlantic and Indian Ocean Sectors of the Southern Ocean.

Notable exceptions to the generalization of genetic homogeneity in the pelagic zooplankton populations in the Southern Ocean are the conclusions of Bucklin and her co-workers. Western Atlantic populations of Labidocera aestiva (Bucklin \& Marcus 1985), North Atlantic Slope Water euphausiid populations (Bucklin \& Weibe 1986) and California Current populations of Euphausia pacifica (Bucklin 1986) and Metridia pacifica (Bucklin et al. 1989, Bucklin 1991) all showed some evidence of genetic structuring. Although much work has been done on planktonic crustacea, no biochemical analyses have been performed to elucidate the population structure of other zooplanktonic taxa in the marine environment.

Parasagitta elegans (Verrill) is a relatively large boreal chaetognath which is most abundant in neritic waters. Its usual southernmost limit of occurrence is the lower boundary of the Pacific Subarctic Water (Bieri 1959), and it is known as an indicator species of the Oyashio Current. Eukrohnia hamata (Möbius) is a cosmopolitan pelagic chaetognath which appears close

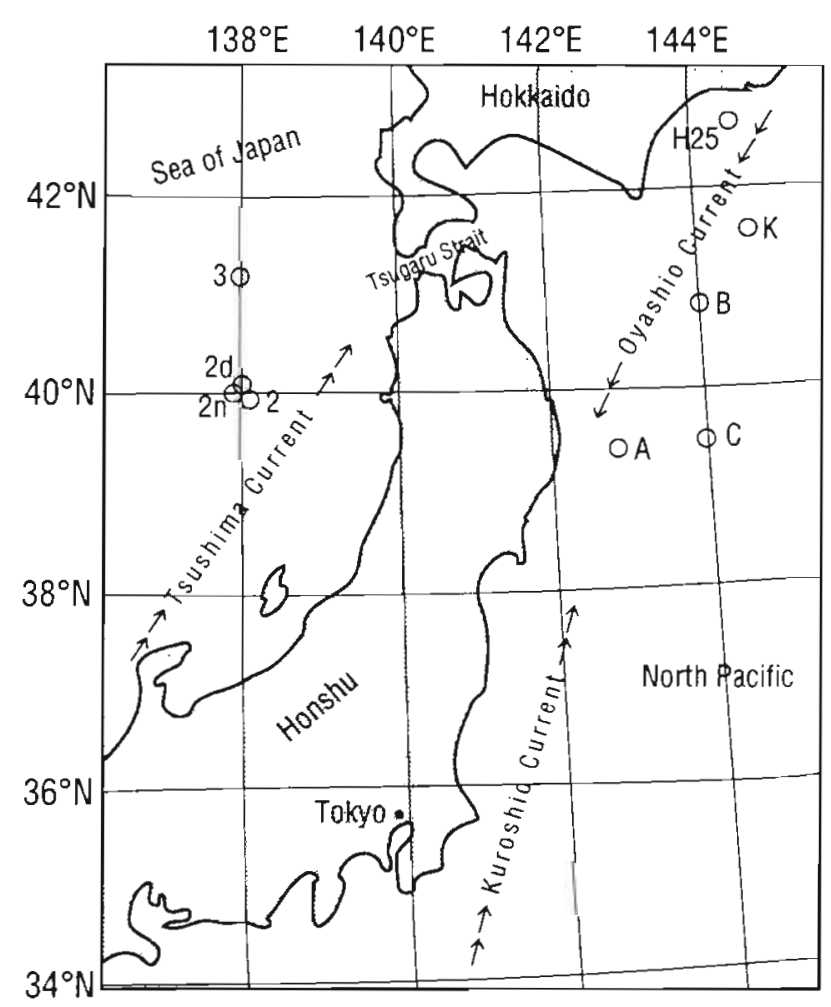

Fig. 1 Locations of sampling stations off the coast of Japan. Station data given in Table 1 to the surface in arctic and antarctic waters and submerges in lower latitudes (Bieri 1959). In the Sea of Japan, $P$. elegans is generally found north of $37^{\circ}$ (Tokioka 1940). The exchange of water in the northern Sea of Japan is fairly limited (Zenkevitch 1963, Nishimura 1969), and meso- and bathypelagic chaetognaths such as E. hamata, E. bathypelagica and Caecosagitta macrocephala that are common in the Pacific Ocean are absent from the Sea of Japan. Although it is thought that in late summer the warm Tsushima Current can reach around the northern end of Honshu, Japan, through the Tsugaru Strait and apparently carry zooplankton populations from the Sea of Japan to the eastern side of Honshu (Furuhashi 1984), it is not known to what extent the exchange of northern zooplankton populations occurs through the shallow northern straits connecting with the Sea of Okhotsk and the Pacific Ocean. The Mamiya Strait, Soya Strait and Tsugaru Strait are 5, 53 and $130 \mathrm{~m}$ in depth respectively (Zenkevitch 1963). The present study was undertaken to compare the genetic composition of $P$. elegans in the Sea of Japan with that in the Oyashio and to increase our understanding of the genetic structure of zooplankton populations in general

\section{METHODS}

Chaetognath specimens. Plankton sampling was undertaken on the RV 'Tansei Maru' during cruises KT-87-7 to the Sea of Japan, and KT-87-11 to the Oyashio-Kuroshio mingling waters off the northern coast of Honshu (the main island of Japan), cruise KH87-4 of the RV 'Hakuho Maru' to the Kuroshio warm core ring area and the Oyashio south of Hokkaido, Japan, and the RV 'Iwate Maru' Salmon I cruise of the Kamaishi Iwate Prefectural Fisheries Station (Fig. 1). Several types of sampling apparatus were used to collect specimens. Oblique tows of ORI nets (Omori 1965), horizontal tows of MTD closing nets (Motoda 1971), and a $113 \mathrm{~cm}$ diameter fish larvae net were employed as listed in Table 1.

The chaetognath specimens removed from 1 net tow were considered to comprise 1 population sample. Population samples of Parasagitta elegans were collected at stations in the Sea of Japan and Oyashio (Table 1). Populations samples of Eukrohnia hamata were collected in the Oyashio and Kuroshio warm core ring area (Table 1). Chaetognaths were immediately removed from the plankton samples before the addition of any preservatives, and identified with a binocular microscope. Only mature individuals in good condition were taken for analyses. Chaetognaths are commonly cannibalistic predators and occasionally contain visible parasites. Only specimens without visi- 
Table 1. Chaetognath population samples

\begin{tabular}{|c|c|c|c|c|}
\hline No. & Date & Stn & Net & Depth $(\mathrm{m})$ \\
\hline \multicolumn{5}{|c|}{ Parasagitta elegans } \\
\hline 51 & 20 Apr 1987 & A & Ring net & $0-68$ \\
\hline 31 & 10 Jun 1987 & 2 & MTD & 250 \\
\hline 28 & 10 Jun 1987 & $2 d$ & ORI & $0-669$ \\
\hline 13 & 10 Jun 1987 & $2 n$ & MTD & 50 \\
\hline 41 & 11 Jun 1987 & 3 & ORI & $0-334$ \\
\hline 15 & 12 Jun 1987 & $\mathrm{~B}$ & ORI & $0-322$ \\
\hline 30 & 12 Sep 1987 & $\mathrm{H} 25$ & MTD & 200 \\
\hline \multicolumn{5}{|c|}{ Eukrohnia hamata } \\
\hline 40 & 12 Jun 1987 & $\mathrm{C}$ & ORI & $0-347$ \\
\hline 35 & 13 Aug 1987 & $\mathrm{~K}$ & MTD & 250 \\
\hline
\end{tabular}

ble gut contents or parasites were used to avoid the possibility of sample contamination. While still living, chaetognaths were rinsed very briefly in distilled water to remove excess salt, immediately blotted dry on filter paper to remove excess water, and frozen in liquid nitrogen. Specimens were transported to the laboratory and remained in liquid nitrogen until use with one exception, when animals which had been originally frozen in liquid nitrogen were transported while stored in dry ice.

Chaetognaths were homogenized with a glass rod in welled glass plates either on ice or in a $5^{\circ} \mathrm{C}$ cold room. Rectangular pieces of filter paper $(5.0 \times 1.5 \mathrm{~mm})$ were applied directly to the sample homogenate without the addition of any extraction buffer, adapting the methods of Numachi (1971) to smaller sample size. These filter papers containing chaetognath cell lysates were then applied to the starch gels. This method of preparation allowed each chaetognath specimen to be examined at every enzyme locus.

Starch gel electrophoresis and interpretation of electrophoretic data. Horizontal starch gel electrophoresis was performed following the methods outlined by Numachi et al. (1979). Four buffer systems were selected for the preparation and running of gels. Three CAEA buffer systems [citric acid and $\mathrm{N}$-(3-amino-propyl)-diethanolamine with (1) NADP, (2) NADP and EDTA and (3) NADP, ATP and $\mathrm{Mg}^{+}$, all at $\mathrm{pH}$ 7.01, were adapted from Clayton \& Tretiak (1972), and the preparation of TBE buffer (Tris, boric acid and EDTA with NAD and ATP; $\mathrm{pH} 8.7$ ) followed Kraus \& Neely (1964). Starch gels of $12.5 \%$ and $6 \mathrm{~mm}$ thick were run at a constant current (CAEA buffers $3.6 \mathrm{~mA} \mathrm{~cm}^{-2}$; TBE buffer $2.0 \mathrm{~mA} \mathrm{~cm}^{-2}$ ) until a control marker of amide black $10 \mathrm{~B}$ migrated a distance of $5 \mathrm{~cm}$.

Each gel was sliced into 6 sheets $1 \mathrm{~mm}$ thick and stained for enzymes according to Shaw \& Prasad (1970) and Numachi et al. (1979). A survey of 34 enzyme systems was carried out to identify enzyme loci capable of serving as genetic markers. Sixteen enzyme systems were found to be routinely assayable and were chosen for investigation. Stained gels were preserved between cellophane sheets for future analysis following the methods given by Numachi (1981). The naming of loci and alleles follows that described by Shaklee et al. (1990). The most common allele at each enzyme locus was scored as 100 and all other alleles were referred to as 100 plus or minus the distance (in $\mathrm{mm}$ ) of electrophoretic mobility greater or less than this standard allele

Indices of genetic variation were calculated for electrophoretic data according to Ayala \& Valentine (1978). Heterozygosity $(H)$ was measured as the observed frequency of heterozygotes per locus averaged over all loci in the sample. The proportions of enzyme loci in a sample which were polymorphic at greater than $5 \%$ and $1 \%$ of the loci observed were expressed as $P_{095}$ and $P_{0.99}$, respectively. $\chi^{2}$ analyses were performed to determine if the population samples were representative of panmictic populations or genetically structured. When necessary, $\chi^{2}$ calculations adjusted for small sample size were performed according to Sokal \& Rohlf (1981). Nei's (1972) measure of genetic distance (D) was computed in order to quantify the genetic differentiation which was observed between chaetognath population samples, and a dendrogram was constructed using the unweighted pair-group method using arithmetic averages (UPGMA; Sneath \& Sokal 1973) to illustrate the genetic divergence between population samples.

\section{RESULTS}

Nineteen loci encoding 16 enzymes were resolved for Parasagitta elegans and were the primary focus of this study (Table 2). In addition, 15 loci encoding 12 enzymes of Eukrohnia hamata were stained with sufficient clarity for analysis (Table 2). The glycolytic enzymes lactate dehydrogenase, octopine dehydrogenase, strombine dehydrogenase and alanopine dehydrogenase could not be detected in either of these chaetognaths, although many buffer systems at several different $\mathrm{pHs}$ were used in the preliminary survey. Eukrohnia hamata shared no common alleles with $P$. elegans at any of the enzyme loci examined.

Alleles and allele frequencies of the 8 polymorphic enzyme loci examined for 7 population samples of Parasagitta elegans are presented in Table 3. Alleles and allele frequencies of the 3 polymorphic enzyme loci resolved for the 2 population samples of Eukrohnia hamata are presented separately (Table 4). Both species of chaetognaths were found to display low levels 
Table 2. Parasagitta elegans and Eukrohnia hamata. Chaetognath enzyme loci. na: not assayed

\begin{tabular}{|c|c|c|c|}
\hline Enzyme (E.C. no.) & Buffer & P. elegans loci & E. hamata loci \\
\hline Acid phosphatase (3.1.3.2) & CAEA 2 & $A C P$ & $A C P$ \\
\hline Adenylate kinase $(2.7 .4 .3)$ & CAEA 2 & $A K$ & $A K$ \\
\hline Asparate aminotransferase $(2.6 .1 .1)$ & CAEA 2 & $A A T$ & $A A T$ \\
\hline Esterase (3.1.1.1) & CAEA 1 & $E S T$ & $E S T-1, E S T-2$ \\
\hline Glutathione reductase $(1.6 .4 .2)$ & CAEA 1 & GLR & $G L R$ \\
\hline Glycerol-3- $\mathrm{PO}_{4}$ dehydrogenase $(1.2 .1 .12)$ & TBE & $G 3 P D H$ & G3PDH-1, G3PDH-2 \\
\hline Isocitrate dehydrogenase $(1.1 .1 .42)$ & CAEA 3 & $I C D-1, I C D-2$ & $I C D-1, I C D-2$ \\
\hline Leucine aminopeptidase (3.4.11.?) & TBE & LAP & $L A P$ \\
\hline Malate dehydrogenase (1.1.1.37) & CAEA 3 & $M D H$ & $\mathrm{MDH}$ \\
\hline Malic enzyme $(1.1 .1 .40\}$ & CAEA2 & $M E-1, M E-2$ & $M E$ \\
\hline Mannose phosphate isomerase (5.3.1.8) & TBE & MPI & na \\
\hline Peptidase [LeucylGlycine] (3.4.13.?) & CAEA 3 & $P E P-1, P E P-2$ & na \\
\hline Phosphoglucomutase $(2.7 .5 .1)$ & TBE & $P G M$ & PGM \\
\hline 6-Phosphogluconate dehydrogenase (1.1.1.44) & CAEA 1 & $6-P G D$ & $6-P G D$ \\
\hline Phosphohexose isomerase $(5.3 .1 .9)$ & CAEA 3 & PHI & na \\
\hline Pyruvate kinase $(2.7 .1 .40)$ & CAEA 2 & $P K$ & na \\
\hline
\end{tabular}

Table 3. Parasagitta elegans. Allele frequencies of polymorphic loci. nd: not determined

\begin{tabular}{|c|c|c|c|c|c|c|c|c|}
\hline \multirow[t]{2}{*}{ Locus } & \multirow[t]{2}{*}{ Alleles } & \multicolumn{4}{|c|}{ Sea of Japan } & \multicolumn{3}{|c|}{ Oyashio } \\
\hline & & 2 & $2 \mathrm{~d}$ & $2 n$ & 3 & A & B & $\mathrm{H} 25$ \\
\hline \multirow[t]{4}{*}{$A A T$} & $\mathrm{n}$ & 31 & 28 & 13 & 41 & 47 & 15 & 30 \\
\hline & $\cdot 92$ & 0 & 0 & 0 & 0 & 0.011 & 0 & 0 \\
\hline & $\cdot 96$ & 0 & 0 & 0 & 0.012 & 0.245 & 0.067 & 0.450 \\
\hline & $\cdot 100$ & 1.000 & 1.000 & 1.000 & 0.988 & 0.745 & 0.933 & 0.550 \\
\hline \multirow[t]{3}{*}{$G L R$} & $\mathrm{n}$ & 31 & nd & 9 & 41 & 51 & 15 & 30 \\
\hline & $\cdot 100$ & 0.968 & - & 0.944 & 0.963 & 0.863 & 1.000 & 0.833 \\
\hline & $\cdot 103$ & 0.032 & - & 0.056 & 0.037 & 0.137 & 0 & 0.167 \\
\hline \multirow[t]{3}{*}{ G3PDH } & $n$ & 31 & 28 & 13 & 41 & 47 & 15 & 30 \\
\hline & $\cdot 100$ & 1.000 & 0.982 & 1.000 & 1.000 & 1.000 & 1.000 & 1.000 \\
\hline & $\cdot 103$ & 0 & 0.018 & 0 & 0 & 0 & 0 & 0 \\
\hline \multirow[t]{3}{*}{$I C D-1$} & $\mathrm{n}$ & 31 & nd & 13 & 41 & nd & 15 & 30 \\
\hline & $\cdot 98$ & 0.016 & - & 0 & 0 & - & 0 & 0 \\
\hline & $\cdot 100$ & 0.984 & - & 1.000 & 1.000 & - & 1.000 & 1.000 \\
\hline \multirow[t]{3}{*}{$I C D-2$} & $n$ & 31 & 28 & 13 & 41 & 51 & 15 & 30 \\
\hline & $\cdot 95$ & 0.016 & 0.054 & 0.038 & 0.073 & 0.039 & 0 & 0.017 \\
\hline & $\cdot 100$ & 0.984 & 0.946 & 0.962 & 0.927 & 0.961 & 1.000 & 0.983 \\
\hline \multirow[t]{3}{*}{$M D H$} & n & 31 & 28 & 13 & 41 & 51 & 15 & 30 \\
\hline & $\cdot 100$ & 0.935 & 0.982 & 0.962 & 0.988 & 0.980 & 1.000 & 1.000 \\
\hline & $\cdot 106$ & 0.065 & 0.018 & 0.038 & 0.012 & 0.020 & 0 & 0 \\
\hline \multirow[t]{4}{*}{$M E-1$} & $\mathrm{n}$ & 31 & 28 & 13 & 41 & 51 & 15 & 30 \\
\hline & $\cdot 96$ & 0 & 0 & 0 & 0.012 & 0 & 0 & 0 \\
\hline & $\cdot 100$ & 1.000 & 1.000 & 1.000 & 0.976 & 1.000 & 1.000 & 1.000 \\
\hline & $\cdot 102$ & 0 & 0 & 0 & 0.012 & 0 & 0 & 0 \\
\hline \multirow[t]{8}{*}{ PHI } & $\mathrm{n}$ & 31 & 28 & 13 & 41 & 51 & 15 & 30 \\
\hline & $\cdot 90$ & 0.016 & 0 & 0.038 & 0 & 0 & 0 & 0 \\
\hline & $\cdot 94$ & 0 & 0 & 0 & 0 & 0 & 0.067 & 0 \\
\hline & $\cdot 96$ & 0.048 & 0 & 0 & 0.037 & 0.010 & 0 & 0 \\
\hline & $\cdot 98$ & 0.097 & 0 & 0 & 0.012 & 0.029 & 0 & 0.017 \\
\hline & $\cdot 100$ & 0.806 & 0.964 & 0.962 & 0.939 & 0.951 & 0.933 & 0.967 \\
\hline & $\cdot 102$ & 0 & 0 & 0 & 0 & 0.010 & 0 & 0 \\
\hline & $\cdot 104$ & 0.032 & 0.036 & 0 & 0.012 & 0 & 0 & 0 \\
\hline
\end{tabular}


Table 4. Eukrohnia hamata. Allele frequencies of polymorphic loci

\begin{tabular}{|c|c|c|c|}
\hline \multirow[t]{2}{*}{ Locus } & \multirow[t]{2}{*}{ Allele } & \multicolumn{2}{|c|}{ Station } \\
\hline & & C & $K$ \\
\hline \multirow[t]{3}{*}{ 6PGD } & $\mathrm{n}$ & 40 & 32 \\
\hline & $\cdot 96$ & 0.250 & 0.016 \\
\hline & $\cdot 100$ & 0.750 & 0.984 \\
\hline \multirow[t]{4}{*}{$M D H$} & $\mathrm{n}$ & 40 & 33 \\
\hline & $\cdot 95$ & 0.138 & 0.152 \\
\hline & $\cdot 100$ & 0.812 & 0.666 \\
\hline & $\cdot 105$ & 0.050 & 0.182 \\
\hline \multirow[t]{3}{*}{$M E$} & $\mathrm{n}$ & 40 & 35 \\
\hline & $\cdot 95$ & 0.013 & 0 \\
\hline & $\cdot 100$ & 0.987 & 1.000 \\
\hline
\end{tabular}

Table 5. Parasagitta elegans and Eukrohnia hamata. Genetic heterozygosity $(H)$ and proportion of polymorphic loci at $5 \%$ $\left(P_{095}\right)$ and $1 \%\left(P_{0.99}\right)$ in chaetognath population samples

\begin{tabular}{|c|c|c|c|c|}
\hline Sample & No. & $P_{0.95}$ & $P_{099}$ & $H$ \\
\hline \multicolumn{5}{|c|}{ Parasagitta elegans } \\
\hline 2 & 31 & 0.111 & 0.278 & 0.025 \\
\hline $2 d$ & 28 & 0.062 & 0.250 & 0.016 \\
\hline $2 n$ & 13 & 0.055 & 0.222 & 0.021 \\
\hline 3 & 41 & 0.111 & 0.278 & 0.023 \\
\hline A & 51 & 0.118 & 0.294 & 0.036 \\
\hline $\mathrm{B}$ & 15 & 0.111 & 0.111 & 0.025 \\
\hline $\mathrm{H} 25$ & 30 & 0.167 & 0.222 & 0.035 \\
\hline Averag & & 0.105 & 0.236 & 0.026 \\
\hline \multicolumn{5}{|c|}{ Eukrohnia hamata } \\
\hline C & 40 & 0.133 & 0.200 & 0.047 \\
\hline K & 35 & 0.067 & 0.133 & 0.029 \\
\hline Averag & & 0.100 & 0.167 & 0.038 \\
\hline
\end{tabular}

of genetic heterozygosity (Table 5) and low proportions of polymorphic loci (Table 5) in all population samples.

Expected phenotype frequencies matched with observed phenotype frequencies in most of the population samples according to $\chi^{2}$ analyses. However, devia-

Table 6. Parasagitta elegans. Nei's genetic distance between population samples

\begin{tabular}{|lcccccc|}
\hline Sample & $\mathrm{H} 25$ & $\mathrm{~B}$ & 3 & $2 \mathrm{n}$ & $2 \mathrm{~d}$ & 2 \\
\hline $\mathrm{A}$ & 0.0023 & 0.0030 & 0.0037 & 0.0038 & 0.0044 & 0.0050 \\
2 & 0.0134 & 0.0014 & 0.0011 & 0.0011 & 0.0012 & \\
$2 \mathrm{~d}$ & 0.0126 & 0.0006 & 0.0002 & 0.0003 & & \\
$2 \mathrm{n}$ & 0.0118 & 0.0007 & 0.0002 & & & \\
3 & 0.0116 & 0.0007 & & & & \\
$\mathrm{~B}$ & 0.0095 & & & & & \\
\hline
\end{tabular}

tions from Hardy-Weinberg equilibrium due to homozygous excesses were observed at the AAT and $G L R$ loci $\left(\chi_{\text {ad }[1]}^{2}=3.99, \mathrm{p}<0.05\right.$ and $\chi_{\text {adj[1] }}^{2}=4.26, \mathrm{p}<$ 0.05 , respectively) in the Stn A population sample and at the $A A T$ locus $\left(\chi_{\text {adji1j }}^{2}=4.33, p<0.05\right)$ in the Stn $\mathrm{H} 25$ population sample. The occurrence of rare alleles at the PHI locus in population samples from the Sea of Japan also resulted in statistical deviations from Hardy-Weinberg equilibrium, however expected $\chi^{2}$ distributions were observed when rare heterozygotes were excluded from the data set.

Allele frequencies at polymorphic loci were mostly similar across all population samples for Parasagitta elegans. Noticeable exceptions were found at the $A A T$ and GLR loci (Table 3). The 2 most polymorphic loci of Eukrohnia hamata displayed different allele frequencies between the 2 population samples (Table 4). Comparisons of genetic distance (Table 6) showed that $P$. elegans population samples were very similar. Two of the 3 Oyashio population samples (Stns A \& H25) were more closely related to each other and to the third Oyashio population sample than to the population samples from the Sea of Japan. The Sea of Japan population samples showed higher similarity to each other. These relationships are represented diagrammatically in a dendrogram generated by UPGMA (Fig. 2). Although the genetic distances between population samples were small, analysis by UPGMA resulted in the formation of 2 groups: 2 Oyashio population samples, A and $\mathrm{H} 25$, forming one group and the Sea of Japan samples along with the small homogeneous Oyashio population sample from Stn B forming the other group. Nei's $D$ was calculated for the $2 E$. hamata population samples at 0.0052 . 


\section{DISCUSSION}

\section{Population structure of chaetognaths}

Population structuring has been defined as genetic differences arising among populations due to barriers which prevent interbreeding (cf. Avise \& Felley 1979). The low percentages of polymorphic loci and low level of heterozygosity displayed at these loci rendered both Parasagitta elegans and Eukrohnia hamata difficult subjects for the investigation of such population structuring. However the differences in allele frequencies which were observed between population samples suggest that some genetic structuring of these populations over the study area does exist.

Although only a few differences were seen in allele frequencies between Parasagitta elegans population samples from the Sea of Japan and Oyashio, analysis by UPGMA showed a tendency to group 2 of the Oyashio population samples together. This result was due to the higher frequencies of AAT*96 and GLR*103 alleles found in these population samples. Effects of small sample size may partially explain the lower frequencies found in the third Oyashio population sample. The differences in allele frequencies at these 2 loci suggest that barriers exist between the $P$. elegans populations of the Sea of Japan and the Oyashio. If these results are not obscured by small sample size, the observed differences in allele frequencies at this station may present further evidence of genetic structuring and possibly leakage of Sea of Japan populations through the Tsugaru Strait. The similarities in allele frequencies at 3 polymorphic loci between the Stn A and Stn H25 population samples would appear to suggest that these 2 samples come from a single panmictic population, however the marked difference in the allele frequencies at the AAT loci indicates the opposite. The Stn A population sample was taken over $500 \mathrm{~km}$ downstream in the Oyashio and almost 5 mo previous to the Stn H25 population sample.

The differences in allele frequencies at the $2 P_{095}$ loci, $6 P G D$ and $M D H$, of Eukrohnia hamata suggest that the 2 population samples came from at least partially isolated populations, despite smaller differences in spatial and temporal distributions. In contrast to the evidence found supporting the idea of genetic structuring of chaetognath populations in the Pacific study area, the Sea of Japan population samples appear to represent a panmictic population similar to those found in antarctic euphausiids.

Kühl \& Schneppenheim (1986) computed genetic distance values between population samples of 2 species of antarctic krill to be on the order of 0.0002 . They suggested that such low values were indicative of large, panmictic zooplankton populations in the antarctic pelagic ecosystem. Similar allele frequencies between population samples of a hyperiid amphipod in the antarctic environment have been cited as further support of this statement (Schneppenheim \& Weigmann-Haass 1986). The D-values for population samples of Parasagitta elegans (Table 6, Fig. 2) may be interpreted as supporting the idea of panmixis for those population samples in the Sea of Japan with barriers existing with the Oyashio population samples. The one population sample from the Oyashio which refutes this supposition was much smaller than the others possibly accounting for this apparent deviation. The value of $D$ for the 2 population samples of Eukrohnia hamata was similar to that displayed by the $P$. elegans population samples from the Oyashio. The $D$ values reported by Bucklin and co-workers (Bucklin \& Marcus 1985, Bucklin 1986, Bucklin \& Weibe 1986) for planktonic copepods and krill are all of an order of magnitude larger than that reported here for chaetognaths. Albeit their studies were undertaken with relatively low numbers of samples and/or very low numbers of enzyme loci.

Homozygous excesses have been repeatedly observed among marine molluscs (Singh \& Green 1985). Greater frequencies of homozygotes have been found in juveniles than in adults, possibly as a result of selection against homozygosity (Koehn et al. 1973). Moreover, the extent of homozygous excess has been observed to vary greatly among loci (Singh \& Green 1985). Bucklin \& Marcus (1985) observed many heterozygote deficiencies in the planktonic copepod Labidocera aestiva, which they ascribed to restricted gene flow between populations or differences in factors of selection at work on the populations. In contrast, departures from expected $\chi^{2}$ frequencies have been observed as heterozygote excesses in krill (Fevolden 1984). The homozygous excesses found in the 2 Oyashio population samples could be interpreted as an example of the Wahlund effect, i.e. the mixing of 2 separate populations in the sample.

One possible mechanism for such population mixing could be a Bering Sea population combining with one from the Subarctic North Pacific in the Oyashio and therefore accounting for the observed homozygous excesses. Kotori et al. (1986) found that Parasagitta elegans apparently reproduced during winter under the ice in a large lagoon in northern Hokkaido. Transport out of such bays in the Bering Sea, Sea of Okhotsk and coastal waters of the Kamchatka Peninsula may also be able to influence the genetic composition of Oyashio $P$. elegans populations, if neritic breeding populations have different genetic compositions. The effect of founder events or localized patchiness on zooplankton population structure is unknown. It is also possible that current mingling in the Oyashio-Kuroshio area affects 
chaetognath population structure as chaetognaths reach reproductive maturity. Two studies that attempted to elucidate the relationships between physical processes in the ocean and the genetic structure of a pelagic copepod, Metridia pacifica, found no statistically significant correlation between hydrographic features and allozyme allele frequencies (Bucklin et al. 1989, Bucklin 1991).

To date there have been no studies on the life histories and ecology of chaetognaths in the Oyashio Current. Reproduction spans from 6 to 10 mo in pelagic populations of Parasagitta elegans in the eastern North Pacific (Terazaki \& Miller 1986) to $2 \mathrm{yr}$ in neritic populations in the Arctic (Dunbar 1962). Terazaki \& Miller (1986) suggested that there may be genetic differences between stocks of $P$. elegans on the basis of discrepancies in average body lengths. However, Fevolden (1986) found it impossible to correlate electrophoretically detectable genetic differences to such size discrepancies in stocks of Euphausia superba near the Antarctic Peninsula.

A different explanation for the observed homozygous excesses relates to the reproductive biology of Parasagitta elegans. Chaetognaths are hermaphroditic, and some species are evidently capable of selffertilization (Jägersten 1940, Nagasawa 1987). In the course of sorting live $P$. elegans for electrophoretic analysis, mature individuals with sperm streaming out of the seminal vesicles and progressing anteriorly along the body towards the seminal recepticles were observed on several occasions, observations similar to those made by Jägersten (1940). The possibility of selffertilization in $P$. elegans cannot be excluded, and a section of the population utilizing self-fertilization could be responsible for the observed homozygous excesses. The other possible explanation, selective advantage for homozygotes, is not analyzable with the present data, since all of the specimens used in the study were mature adults.

Rare alleles causing deviations from expected $\chi^{2}$ frequencies were found at the PHI locus in the population samples from the Sea of Japan. Some workers have ignored rare alleles in $\chi^{2}$ calculations (Fevolden 1986) and others have interpreted them as being significant (Bucklin \& Marcus 1985). MacDonald et al. (1986) found discrepancies between populations of Euphausia superba due to rare alleles but considered them insignificant in the face of other data overwhelmingly supporting the idea of a large panmictic population of krill. Differences in electrophoretic techniques have prohibited the comparison of results concerning the structure of the relatively well-investigated antarctic krill populations, and it remains unknown what changes occur in the frequencies of rare alleles over time. Furthermore, comparisons of different biochemical genetic techniques have indicated that selection occurring at allozyme loci may obscure population structuring over large geographic areas (Karl \& Avise 1992).

\section{Genetic homogeneity of chaetognaths}

Parasagitta elegans and Eukrohnia hamata both were found to have low levels of $P_{0.99}, P_{0.95}$ and $H$ when compared with those of other marine zooplankton (Table 7). Much discussion and debate has taken place concerning advantages and mechanisms behind enzyme polymorphisms in species and populations (Kimura \& Ohta 1971, Selander \& Kaufman 1973, reviewed in Nei \& Koehn 1983). The 'environmental heterogeneity-trophic diversity' model of Nelson \&

Table 7. Comparison of genetic variation in zooplankton. Parameters as in Table 5

\begin{tabular}{|c|c|c|c|c|c|c|}
\hline Taxa & Location & $P_{099}$ & $P_{0.95}$ & $H$ & $\begin{array}{c}\text { Loci } \\
\text { observed }\end{array}$ & Data source \\
\hline \multicolumn{7}{|l|}{ Euphausiacea } \\
\hline Euphausia superba & Southern Ocean & 0.53 & 0.40 & 0.118 & 15 & Kuhl \& \\
\hline E. Crystallorophias & Southern Ocean & 0.35 & 0.29 & 0.094 & 17 & Schneppenheim (1986) \\
\hline E. krohnii & North Atlantic & 1.00 & 0.75 & 0.230 & 8 & Bucklin \& Weibe (1986) \\
\hline \multicolumn{7}{|l|}{ Copepoda } \\
\hline Labidocera aestiva & Western Atlantic & 1.00 & 0.78 & 0.25 & 6 & Bucklin \& Marcus (1985) \\
\hline Metridia pacifica & California Current & 0.64 & 0.60 & 0.18 & 9 & Bucklin et al.(1989) \\
\hline \multicolumn{7}{|l|}{ Amphipoda } \\
\hline Themisto Libellula & Southern Ocean & 0.88 & 0.33 & 0.133 & 9 & Schneppenheim \& \\
\hline T. gaudichaudii & Southern Ocean & 0.70 & 0.50 & 0.230 & 10 & Weigmann-Haass (1986) \\
\hline \multicolumn{7}{|l|}{ Chaetognatha } \\
\hline Parasagitta elegans & Sea of Japan and Oyashio & 0.24 & 0.11 & 0.026 & 19 & Present study \\
\hline Eukrohnia hamata & Western North Pacific & 0.17 & 0.10 & 0.038 & 15 & Present study \\
\hline
\end{tabular}


Hedgecock (1980) and its predecessors (Selander \& Kaufman 1973, Ayala 1976) have most often been applied to interpretations of zooplankton electrophoretic data (Valentine \& Ayala 1976, Ayala \& Valentine 1979, Fevolden 1984). The low levels of enzyme polymorphism and genetic heterogeneity observed in P. elegans and E. hamata match well with that predicted for fine-grained adaptive strategists by the 'environmental heterogeneity-trophic diversity' model proposed by Nelson \& Hedgecock (1980). Comparisons of the genetic diversity data for $P$. elegans and E. hamata are difficult to perform, since both display such low levels of variation. Although some difficulties are inherent in these methods of investigation and analysis, it should be considered profitable to analyze biochemical genetic differences in planktonic taxa to gain insights into their biology, ecology and distribution patterns. Newer techniques of molecular biology should prove to be very fruitful towards achieving this goal (Powers et al. 1990, Falkowski \& Laroche 1991).

\section{Phylogenic implications}

Much speculation concerning the phylogenic relationships between the $100+$ species that belong to the phylum Chaetognatha has occurred, but few analytical analyses have been undertaken (Bieri 1991). Tokioka $(1965 \mathrm{a}, \mathrm{b})$ erected a taxonomic system which described the higher taxonomic categories of the Chaetognatha and split the most common genus, Sagitta, into 9 different genera. In contrast to the low levels of conspecific variation which were observed in this study, electrophoretic results show that a very large phylogenetic gap exists between Eukrohnia hamata, a member of the order Phragmophora Tokioka, and Parasagitta elegans, a member of the order Aphragmophora Tokioka. Our data are therefore in agreement with Tokioka's division of these 2 chaetognath suprataxa. A large-scale electrophoretic study of chaetognath enzyme loci would no doubt be very valuable to elucidate phylogenetic relationships within the phylum.

Acknowledgements. We thank Dr M. Terazaki for his unfailing encouragement and support, and Dr T. Kobayashi for helpful advice concerning electrophoresis, which was carried out at the Otsuchi Marine Research Center of the Ocean Research Institute, University of Tokyo. Our deep appreciation is extended to the captains, crews and scientists of the research vessels 'Tansei Maru', 'Hakuho Maru' and 'Iwate Maru' for their assistance with sampling at sea. Dr $T$. Kobayashi and M. Ogura kindly provided us with their computer programs for analysis of electrophoretic data. Drs C. B. Miller and T. McClelland are thanked for constructive criti- cism on an earlier draft of this manuscript. This study was supported in part by the Ministry of Education, Science and Culture, Japan (Monbushô) and the Nissan Science Foundation.

\section{LITERATURE CITED}

Avise, J. C., Felley, J. (1979), Population structure of freshwater fishes 1. Genetic variation of Bluegill (Lepomis macrochirus) populations in man-made reservoirs. Evolution 33: 15-26

Ayala, F. J. (ed.) (1976). Molecular evolution. Sinauer Associates, Sunderland, MA

Ayala, F. J., Valentine, J. W. (1978). Genetic variation and resource stability in marine invertebrates. In: Battaglia, $B$., Beardmore, J. A. (eds.) Marine organisms: genetics, ecology and evolution. Plenum Press, New York, p. 23-51

Ayala, F. J., Valentine, J. W. (1979). Genetic variability in the pelagic environment: a paradox? Ecology 60:24-29

Ayala, F. J., Valentine, J. W., Zumwalt, G. S. (1975). An electrophoretic study of the antarctic zooplankter Euphausia superba. Limnol. Oceanogr. 20: 635-640

Bieri, R. (1959). The distribution of the planktonic Chaetognatha in the Pacific and their relationship to the water masses. Limnol. Oceanogr. 4: 1-28

Bieri, R. (1991). Systematics of the Chaetognatha. In: Bone, Q., Kapp, H., Pierrot-Bults, A. C. (eds.) The biology of chaetognaths. Oxford University Press, Oxford, p. $122-136$

Bucklin, A. (1986). The genetic structure of zooplankton populations. Tech. Pap. mar. Sci. (Unesco) 49: 35-41

Bucklin, A. (1991). Population genetic responses of the planktonic copepod Metridia pacifica to a coastal eddy in the California Current. J, geophys. Res. 96: 14799-14808

Bucklin, A., Marcus, N. H. (1985). Genetic differentiation of populations of the planktonic copepod Labidocera aestiva. Mar. Biol. 84: 219-224

Bucklin, A., Rienecker, M. M., Mooers, C. N. K. (1989). Genetic tracers of zooplankton transport in coastal filaments off northern California. J. geophys. Res. 94: $8277-8288$.

Bucklin, A., Weibe, P. (1986). Genetic heterogeneity in euphausiid populations: Euphausia krohnii and Nematoscelis megalops in North Atlantic Slope Water. Limnol. Oceanogr. 31: 1346-1352

Clayton, J. W., Tretiak, D. N. (1972). Amine citrate buffers for pH control in starch gel electrophoresis. J. Fish. Res. Bd Can. 29: 1169-1172

Dunbar, M. J. (1962). The life cycle of Sagitta elegans in Arctic and Subarctic seas, and the modifying effects of hydrographic differences in the environment. J mar. Res. 20 $76-91$

Falkowski, P. G., Laroche, J. (1991) Molecular biology in studies of ocean processes. Int. Rev. Cytol. 128: 261-303

Fevolden, S. E. (1982). Feeding habits and enzyme polymorphism in Thysanoessa raschi and Meganyctiphanes norvegica (Crustacea; Euphausiacea). Sarsia 67: 1-10

Fevolden, S. E. (1984). Biotic and physical environmental impact of genetic variation of krill. J. crust. Biol. 4 (Spec No. 1): $206-223$

Fevolden, S. E. (1986). Genetic variation of Euphausia superba Dana in the Antarctic Peninsula waters. Sarsia 71. $169-175$

Fevolden, S. E., Ayala, F. J. (1981) Enzyme polymorphism in Antarctic krill (Euphausiacea); genetic variation between populations and species. Sarsia 66: 167-181 
Fevolden, S. E., Schneppenheim, R. (1988). Genetic population structure of Euphausia superba Dana in the Atlantic Sector of the Southern Ocean as demonstrated by different electrophoretic techniques. Polar Biol. 9: 1-8

Fevolden, S. E., Schneppenheim, R. (1989). Genetic homogeneity of krill (Euphausia superba Dana) in the Southern Ocean. Polar Biol. 9: 533-539

Furuhashi, K. (1984). Hokkaidounanpoukaiiki no doubutsupurankuton no bunpu ni oyobosu dansuikai no eikyou. Mar. Sci. (Kaiyou Kagaku) 16: 457-461

Jägersten, G. (1940). Zur Kenntnis der Physiologie der Zeugung bei Sagitta. Zool. Bijdr. 18: 397-413

Karl, S. A., Avise, J. C. (1992). Balancing selection at allozyme loci in oysters: implications from nuclear RFLPs. Science 256: $100-102$

Kimura, M., Ohta, T. (1971) Protein polymorphism as a phase of molecular evolution. Nature 229: $467-469$

Koehn, R. K., Turano, F. J., Mitton, J. B. (1973). Population genetics of marine pelecypods. II. Genetic differences in microhabitats of Modiolus demissus. Evolution 27: 100-105

Kotori, M., Nishiyama, T., Tanimura, A., Watanabe, K. (1986) Abundance and vertical distribution of the chaetognath Parasagitta elegans (Verrill) under the sea ice in Saroma Ko, a lagoon on Hokkaido, Japan. Proc. National Institute of Polar Research Symposia on Polar Biology (Tokyo, Japan) 1: 138-144

Kraus, A. P., Neely, C. L. (1964). Human erythrocyte lactate dehydrogenase: four genetically determined variants. Science 145: 595-597

Kühl, S., Schneppenheim, R. (1986). Electrophoretic investigation of genetic variation in two krill species Euphausia superba and E. crystallorophias (Euphausidae). Polar Biol. 6: 17-23

MacDonald, C. M., Williams, R., Adams, M. (1986). Genetıc variation and population structure of krill (Euphausia superba Dana) from the Prydz Bay region of antarctic waters. Polar Biol. 6: 233-237

Motoda, S. (1971). Devices of simple plankton apparatus. V. Bull. Fac. Fish. Hokkaido Univ. 22: 101-106

Nagasawa, S. (1987). Sperm emission in the chaetognath Sagitta crassa. J. Plankton Res. 9: 755-759

Nei, M. (1972). Genetic distance between populations. Am Nat. 106: 281-292

Nei, M., Koehn, R. K. (eds.) (1983). Evolution of genes and proteins. Sinauer Press, Sunderland, MA

Nelson, K., Hedgecock, D. (1980). Enzyme polymorphism and adaptive strategy in the decapod crustacea. Am. Nat. 116: $238-280$

Nishimura, S. (1969). The zoological aspects of the Japan Sea Part V. Publs Seto mar. biol. Lab. 17: 67-142

Numachi, K. (1971). Genetic polymorphism of a-glycerophosphate dehydrogenase in saury, Cololabis saira. I. Seven

This article was submitted to the editor variant forms and genetic control. Bull. Jap. Soc. scient. Fish. 37: 755-760

Numachi, K. (1981). A simple method for scanning and preservation of starch gels. Biochem. Genet. 19: 233-236

Numachi, K., Nagahora, S., Iwata, M. (1979). Genetic demonstration of hybrids between chum and pink salmon in the northwest Pacific. Rep. Otsuchi mar Res. Cent., Iwateken, Japan 5: 87-102

Omori, M. (1965). A $160-\mathrm{cm}$ opening closing plankton net J. oceanogr. Soc. Japan 21: 212-220

Powers, D. A., Allendorf, F. W., Chen, T. (1990). Application of molecular techniques to the study of marine recruitment problems. In: Sherman, K., Alexander, L. M., Gold, B. D. (eds.) Large marine ecosystems: patterns, processes, and yields. American Association for the Advancement of Science, Washington, DC, p. 104-121

Schneppenheim, R., MacDonald, C. M. (1984). Genetic variation and population structure of krill (Euphausia superba) in the Atlantic Sector of antarctic waters and of the Antarctic Peninsula. Polar Biol. 3: 19-28

Schneppenheim, R., Weigmann-Haass, R. (1986). Morphological and electrophoretic studies of the genus Themisto (Amphipoda; Hyperiidea) from the south and north Atlantic. Polar Biol. 6: 215-225

Selander, R. K., Kaufman, D. W. (1973). Genic variability and strategies of adaptation in animals. Proc. natl Acad. Sci. U.S.A. 70: 1875-1877

Shaklee, J. B., Allendorf, F. W., Morizot, D. C., Whitt, G. S. (1990). Gene nomenclature for protein-coding loci in fish. Trans. Am. Fish. Soc. 119: 2-15

Shaw, C. R., Prasad, R. (1970). Starch gel electrophoresis - a compilation of recipes. Biochem. Genet. 4: 297-320

Singh, S. M., Green, R. H. (1985). Excess homozygosity in marine molluscs and its possible biological significance. Malacologia 25: 569-581

Sneath, P. H. A., Sokal, R. R. (1973). Numerical taxonomy, W. H. Freeman \& Co., San Francisco

Sokal, R. R., Rohlf, F. J. (1981), Biometry. W. H. Freeman \& Co., San Francisco

Terazaki, M., Miller, C. B. (1986). Life history and vertical distribution of pelagic chaetognaths at Ocean Station P in the subarctic Pacific. Deep Sea Res. 33: 323-337

Tokioka, T. (1940). The chaetognath fauna of the waters of western Japan. Rec. oceanogr. Wks Japan 12:1-22

Tokioka, T (1965a). The taxonomical outline of the Chaetognatha. Publs Seto mar. biol. Lab. 12: 335-357

Tokioka, T (1965b). Supplementary notes on the systematics of Chaetognatha. Publs Seto mar. biol. Lab. 13: 321-342

Valentine, J. W., Ayala, F. J. (1976). Genetic variability in krill. Proc. natl Acad. Sci. U.S.A. 73: 658-660

Zenkevitch, L. (1963). Biology of the seas of the U.S.S.R. Interscience Publishers, New York

Manuscript first received: April 30, 1992

Revised version accepted: July 26, 1993 